\title{
CUSTOMER RELATIONSHIP MARKETING ON NATIONAL BANKING
}

\section{FRANS SUDIRJO}

Department of Management, University of 17 August 1945 Semarang, Indonesia

\begin{abstract}
This study aims to analyze the effect of commitment on trust, communication on trust, handling complaints on trust, commitment on loyalty, communication on loyalty, handling complaints on loyalty, and trust on loyalty.

The research population is all customers of the National Bank. The sample used is 165 customers. The sampling technique selected non-probabilistically is a technique that does not provide equal opportunities or opportunities for each element or member of the population to be selected as a sample. Data were analyzed using Generalized Structured Component Analysis (GSCA).

The results showed that commitment and complaint handling had a positive effect on trust, while communication had no effect on trust. The results also show that trust has an effect on loyalty, while commitment has no effect on loyalty, communication has no effect on loyalty, and handling complaints has no effect on loyalty.

KEYWORDS: Commitment, Communication, Complaint Handling, Trust \& Loyalty
\end{abstract}

Received: Jun 18, 2021; Accepted: Jul 08, 2021; Published: Jul 23, 2021; Paper Id.: IJBMRDEC20213

\section{INTRODUCTION}

Banking as one of the industries experienced significant progress in Indonesia, resulting in stiff competition nationally and even globally. For the ASEAN region, the size of large banks in the country is still inferior to the size of banks in countries such as Malaysia, Singapore and Thailand, (Setiaatmadja, Info Bank Outlook 2020). Malaysia, Singapore and Thailand have bank sizes three times larger than banks in Indonesia. In terms of capital, banks in Indonesia have credit growth that continues to rise beyond the target, and industrially it can be seen that the banking capital adequacy ratio (CAR) is still better than neighboring countries, as can be seen from; Until the third quarter of 2019, the national banking CAR was recorded at 16.6\%, higher than Singapore at $16.2 \%$, Thailand at $15.5 \%$, Malaysia at $14.6 \%$. Even national banking CAR is much better than European banks, which as of January December 2010 was at the level of 13.2\%. (Setiaatmadja, Bank Info Outlook 2020).

The data above shows that the Indonesian national banking industry is a business that has the potential for development that tends to be good in the future. A large number of national and foreign banks in Indonesia encourages intense competition in the banking business world. The demand for the competition is hard work in improving the quality of services provided as a form of bank competitive advantage.

The results of the 2019 Bank Service Excellence Monitor (BSEM) survey show an indication that the service quality of banks in Indonesia has increased in the last ten years, (http://www.banksulut.co.id). Service is a serious thing to pay attention to, especially in the service industry including banking, because it is a determining factor for the success of a bank (Info BCA. No. 211. Year 2019). One of the strategies undertaken by banks in improving the quality of service to consumers is by implementing a commitment to serving, communicating with customers and handling consumer complaints as a focus in building good relationships with consumers (Ndubisi, 
2007).

Flexible communication and the best commitment in serving consumers, as well as the ability to handle complaints, are important in building and increasing consumer trust (Bowo, 2003). In order to make customers trust the services provided, customers must perceive service quality as a positive thing. Anderson and Narus (2012) emphasize that trust occurs when one party believes that the actions of the other party will give positive results for him. This implies that service quality can have a positive effect on trust, furthermore, trust has been recognized as having an important role in influencing customer loyalty (Gundlach and Murphy, 2009).

Loyalty is the result of establishing long-term good relationships with customers. Running a business requires a relationship-based approach, in order to gain an understanding of what customers need and want and view customers as long-term assets (Barnes, 2010). Bowo, (2014) presents a new model of how to build customer trust. that the factors that can build customer trust are; commitment, communication and complaint handling which then results in long term relationships with customers. Ndubisi (2016) shows that it is variables, commitment, communication and complaint handling that make consumers believe and then be loyal to the bank.

This study aims to analyze how the trust of national bank customers in the services provided through customer relationship marketing and its impact on customer loyalty. This is needed as an evaluation of the paradigm shift in banking services today, namely from the dominance of offline services to the dominance of online services. This shift will certainly have an impact on the current behavior of banking consumers. Information on changes in behavior is very necessary to know and understand so that it can be used as information to take service policies by bank management decision makers.

\section{LITERATURE REVIEW}

Bank as a business entity whose wealth is in the form of financial assets, as well as profit and social motives. Banks in general are financial institutions, money creators, credit collectors and distributors, payment traffic implementers, monetary stabilizers, and economic growth dynamists (Hasibuan, 2017). Banks are fundraisers in the form of deposits which are a source of bank funds and then distributed to the public. In terms of distribution, banks are not merely trying to get the maximum profit for the owner, but also must be directed at improving people's living standards (Siamat, 2015).

In conducting their business, banks need to apply the concept of Customer Relationship Marketing (CRM), which aims to increase the long-term profitability of the company. By approaching consumers who become customers, it means that the bank tries to analyze and understand the needs and expectations of customers for the products or services offered. Chan (2012), explains that CRM is a closer introduction to each customer by creating two-way communication. The communication needs to be managed in the form of a mutually beneficial relationship between the customer and the company. The relationship in question must be a partnership, not just a relationship between a seller and a buyer, to achieve the long-term goal of generating sustainable profits from a loyal customer group. CRM can be used as a strategy in building good relationships with customers in the long term (Winner, 2008). A good CRM will create trust and customer satisfaction and so on will form a loyal customer group, (Tjiptono, 2015). The factors that encourage the formation of customer relationship marketing according to Ndubisi (2007) are commitment, communication and complaint handling that have a direct impact on customer loyalty.

A sustainable business growth strategy can be carried out through a mutualistic symbiotic relationship with customers that allows a business to clearly understand its needs, create and deliver the best value (Ndubisi, 2016). Morgan 
and Hunt (1994) explain that customer commitment is basically a long-lasting desire in the customer to maintain a valuable relationship or relationship that provides benefits (valued relationship), that the customer will have a strong or high commitment if the relationship is considered urgent.

Communication is a process used by consumers and marketing organizations to share information with each other in order to reach a common understanding. It is important to note, if the reception of the information is good, it will spread widely to the target audience, especially for introduction of new products. Information obtained by consumers will usually be related to the decisions taken. Business communication is a form of relationship between communicators and communicants where there is an exchange of ideas, information, messages, and concepts related to the achievement of a series of commercial goals. Communication activities carried out contain elements of persuasion or invitations so that someone is willing to accept understanding and influence, and is willing to carry out an order or inducement.

Conflicts that occur between consumers and companies, can be an opportunity to prove the consistency of promises given to customers through their resolution, as well as information obtained from a willingness to discuss the reasons for their occurrence. Conflict handling is the company's ability to avoid potential conflicts, or resolve conflicts before problems are created, and discuss solutions openly when problems arise (Dweyer et al., 2007). Every customeroriented organization needs to regularly provide ample opportunities for its customers to submit suggestions, opinions and complaints.

Trust is seen as one of the basic and important things in the business world. According to Singh and Sirdeshmukh (2000) trust is the basis for building and maintaining long-term relationships. Trust in marketing theory is the basis of policies for developing and maintaining long-term relationships (Doney and Canon, 2007), creating mutually beneficial relationships with customers and increasing competitiveness (Barney and Hansen, 1994). Confidence or trust is an important factor that can overcome crises and difficulties between business partners, but it is also an important asset in developing long-term relationships between organizations (Karsono, 2008). Organizations that are able to recognize and control trust-forming factors,

Customer loyalty here can be interpreted as a person's loyalty to a company. Therefore, customer loyalty will be the ultimate goal of every company, because the existence of customer loyalty will ensure the continuity of a company in the long term. According to Griffin (2015), loyal customers can be seen from characteristics such as making regular repeat purchases outside the product or service line (referring other), showing immunity from similar products offered by competitors (demonstrates immunity to the full of the competition). Loyal customers will tend to tell positive things or known as positive Word of Mouth (WOM) to others. WOM is a statement conveyed to customers, and this is usually quickly accepted by customers because those who convey it are trustworthy such as experts, friends, family, and mass media publications.

Customers or a company's customer has a deep and important understanding because it can be used to understand why a company should create and maintain customers and not just to attract buyers. Customers in the banking world are better known as consumers. Understanding consumers themselves are all people who demand, because it has an influence on banking performance. Consumers are people who have desires, consumers have arguments, and consumers must be satisfied. 


\section{RESEARCH HYPOTHESIS}

Bowo (2014) uses communication, satisfaction with handling complaints, and commitment as independent variables, and trust as an intervening variable, and long-term relationship as the dependent variable. The results show that trust is built by three main factors, namely communication, satisfaction and commitment, and trust has a positive effect on long-term relationships. These findings underlie the following research hypotheses:

\section{H1: Commitment affects trust \\ $\mathrm{H} 2$ : Communication affects trust \\ H3: Complaint handling affects trust}

Ndubisi (2016), shows that there is an effect of Relationship marketing on customer loyalty. The research variables used are trust, commitment, communication and complaint handling as independent variables, and customer loyalty as the dependent variable. The results of the study reveal that customers tend to be loyal if the bank can be trusted, is committed to service, communicates with customers accurately and efficiently, and is able to handle conflicts well. Therefore, the hypotheses made in this study are:
H4: Commitment affects loyalty.
H5: Communication affects loyalty.
H6: Handling complaints affect loyalty.
H7: Trust has an effect on loyalty.

From the description above, the hypothesis model of this research can be described as Figure 1.

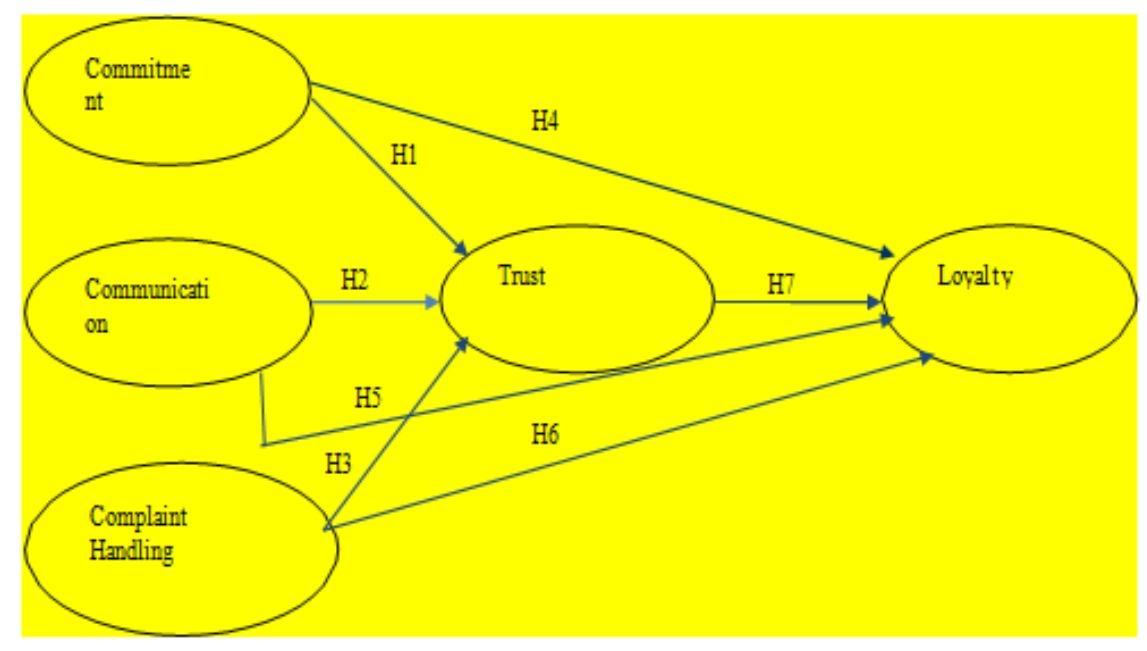

Figure 1: Research Hypothesis Model.

\section{RESEARCH METHODS}

The research population is all customers of the National Banking, so the unit of analysis is the customers of the National Banking. The participant category is customers who often make online transactions (3 times a month) with a minimum savings of Rp. 10 million. Participants were contacted via sms, telephone, BlackBerry network and facebook to fill out 
online questionnaires, and 165 participants were collected as samples that were selected non-probabilistically. Although data processing with the GESCA package program can use not much data, but 165 samples have met the amount of data that will be used in the SEM model, (Ferdinand, 2002).

Operationally, the bank's commitment (X1) is described as an effort shown by national banks to maintain longterm relationships with customers because these relationships are considered valuable and provide benefits. The national banking business can be seen from the products and services offered according to the needs of its customers. Indicators of bank commitment according to Ndubisi (2007), are: a) banks provide guarantees to match products and services with consumer needs, b) banks offer quality products and services and are able to meet customer needs targeted consumers, c) banks are flexible in providing services to consumers, d) banks are able to fulfill their promises to consumers. Bank communication (X2) is a process of exchanging information between the bank and its customers through a system or media, such as telephone, television programs related to banking, banking magazines, or through the bank's website. The indicators of bank communication according to Ndubisi (2007) are: a) banks are able to provide timely information, b) banks are able to provide the latest banking information, c) banks are able to provide accurate information. The variable handling of consumer complaints (X3) is described as an action taken by national banks in dealing with customer dissatisfaction with the products and or services provided. The empirical indicators according to Ndubisi (2007) are:

- The bank is always ready to face the possibility of conflict,

- The bank seeks to resolve conflicts that occur in the service process,

- Banks have the ability to openly discuss solutions when problems arise, d) banks are able to provide satisfactory solutions to problems complained of by consumers.

Trust (Y) is a mediating variable or an intervening variable between customer relationship marketing and consumer loyalty. In this study, the trust in question is the customer's trust in the national banking system. Customer trust is a confident attitude owned by customers towards the products and services offered through concrete actions taken by national banks. The indicators according to Ndubisi (2007) are: a) banks are very concerned with security when consumer transactions, b) banks promise reliable products and services, c) banks are consistent in providing quality services, d) bank employees show respect to customers, e) banks fulfill their obligations to consumers. Consumer loyalty (Z) is an attitude in which consumers consistently use the products and services offered by national banks. The indicators according to Griffin (2015) are: a) repeat purchases of bank products and services continuously (continuously), b) make transactions other than saving, such as paying credit card bills, telephone, or transfer services (rewards), c) recommending the bank's products and services to others (recommendation), d) not interested in switching to another bank (refuse), e) remaining loyal to be a customer of the bank.

Variable measurements were carried out using a Likert scale (scale 1 states strongly disagree with a scale of 5 to state strongly agree) to the statements submitted in the online research questionnaire. Furthermore, data processing is carried out for descriptive analysis using SPSS version 13 software, while causal analysis using Generalized Structured Component Analysis (GSCA) software.

\section{RESULTS}

Respondents who were selected as samples in this study were 165 people and classified based on gender, age, occupation, 
income per month, type of bank used, length of time as a consumer, frequency of transactions per month and type of product used. Participants are samples who are willing to fill out a research questionnaire in accordance with the conditions previously mentioned.

Table 1: Characteristics of Participants

\begin{tabular}{|c|c|c|}
\hline Gender & Frequency & Percent \\
\hline Men & 112 & 68.0 \\
\hline Woman & 53 & 32.0 \\
\hline \begin{tabular}{|r|} 
Total \\
\end{tabular} & 165 & 100.0 \\
\hline Age & Frequency & Percent \\
\hline 17-27 years old & 22 & 13.3 \\
\hline 28-38 years old & 48 & 29.0 \\
\hline 39-49 years old & 61 & 37.0 \\
\hline More than 50 years & 34 & 20.7 \\
\hline $\begin{array}{c}\text { Total } \\
\end{array}$ & 165 & 100.0 \\
\hline
\end{tabular}

The data in table 1 shows that the sample of men is more than women, as many as 112 people (68\%), thus $32 \%$ are women. This composition concludes that research information is dominated by the perception of male respondents. The age group of respondents describes the age group between 39 to 49 years occupying the largest group, namely 61 people (37\%) and the age group 28 to 38 years as much as 48 people or $29 \%$ as the second largest group. This can illustrate that the age group that is active in using banking services with online technology is more dominated by the age group of 28 to 49 years, which is around $66 \%$. Based on the occupations of the first respondents, the largest number of respondents were entrepreneurs, as many as 84 people (51\%) and the second largest group were employees, as many as 40 people (24.2\%). The majority of entrepreneurs, as well as employees, have done online banking financial transactions. Many government and private agencies have used online banking services for business activities, including paying employees' monthly salaries. Based on monthly income between Rp. 9 million to Rp. 13 million as many as 74 people (44.8\%), while the second group is income between Rp. 5 million up to Rp. 9 million, which is about 42 people (25.5\%). Income more than Rp. 13 million only 18 people (10.9\%) were selected as the sample, so it is not yet able to give an idea that the higher a person's income will encourage using online transactions.

Table 2: Employment and Income of Participants

\begin{tabular}{|c|c|c|}
\hline Profession & Frequenc & Percent \\
\hline Student/Student & 5 & 3.0 \\
\hline entrepreneur & 84 & 51.0 \\
\hline Housewife & 16 & 9.7 \\
\hline Employees & 40 & 24.2 \\
\hline Others & 20 & 12.1 \\
\hline Total & 165 & 100.0 \\
\hline Monthly Income & \multicolumn{2}{|c|}{ FrequencyPercent } \\
\hline Less than or equal toIDR 5 million & 31 & 18.8 \\
\hline IDR 5 million -9 million & 42 & 25.5 \\
\hline IDR 9 million -13 million & 74 & 44.8 \\
\hline More than IDR 13 million & 18 & 10.9 \\
\hline \begin{tabular}{|c|} 
Total \\
\end{tabular} & 165 & $\mathbf{1 0 0 . 0}$ \\
\hline
\end{tabular}


Table 3: Bank Services Used and Long Time Being a Consumer

\begin{tabular}{|c|c|c|}
\hline Used Bank & Frequency & Percent \\
\hline Bank BCA & 61 & 37.0 \\
\hline Mandiri Bank & 25 & 15.1 \\
\hline Bank Danamon & 25 & 15.1 \\
\hline CIMB Niaga Bank & 12 & 7.3 \\
\hline Bank BNI & 17 & 10.3 \\
\hline Panin Bank & 4 & 2.4 \\
\hline Bank BRI & 9 & 5.5 \\
\hline Other Banks & 12 & 7.3 \\
\hline Total & 165 & 100.0 \\
\hline Long Time a Consumer & Frequency & Percent \\
\hline 6-12 months & 4 & 3.8 \\
\hline $1-5$ years & 74 & 41.9 \\
\hline 6-10 years & 63 & 31.4 \\
\hline More than 10 years & 24 & 22.9 \\
\hline $\begin{array}{r}\text { Total } \\
\end{array}$ & 165 & 100.0 \\
\hline
\end{tabular}

Based on the type of bank used, there were 61 people (40\%). Based on the length of time being a consumer between 1 to 5 years as many as 44 people (41.9\%). Based on the frequency of transactions that are more than 10 times as many as 36 people $(34.3 \%)$.

Accurate information will depend on the measuring instrument used, for that it is necessary to test the validity and reliability of the measuring instrument. The validity test uses Corrected Item Total Correlation, and information on the results of this test is obtained from the output of SPSS software version 13.0. The results of the commitment variable test (X1) which consists of four indicators with a coefficient of Cronbach's Alpha $=0.801$ and the lowest value is Corrected Item Total Correlation $=0.530$. Communication $(\mathrm{X} 2)$ consists of three indicators, has a coefficient of Cronbach's Alpha $=$ 0.624 and the lowest value is Corrected Item Total Correlation $=0.389$. Complaint Handling (X3) consists of four indicators, has a coefficient of Cronbach's Alpha $=0.795$ and the lowest value is Corrected Item Total Correlation $=0.476$, so the test results explain that the instruments used (X1, X2, and X3) are reliable and valid. Furthermore, for confidence (Y) consists of 5 indicators, and has a coefficient of Cronbach's Alpha $=0.774$ and the lowest value is Corrected Item Total Correlation $=0.394$. Customer loyalty $(\mathrm{Z})$ consists of five indicators and Z has a coefficient of Cronbach's Alpha $=0.740$ and the lowest value is Corrected Item Total Correlation $=0.431$.

To measure the influence between variables, the Generalized Structured Component Analysis (GSCA) package program was used. The influence between variables described by the estimated coefficients of the paths and their significant values are presented in Table 4.

Table 4: Path Coefficients and Significant Values

\begin{tabular}{|l|c|rc|}
\hline \multicolumn{1}{|c|}{ Influence between Variables } & Estima & Cl & P Value \\
\hline Commitment to Trust & 0.33 & 2.90 & 0.004 \\
\hline Commitment to Loyalty & 0.13 & 0.96 & 0.339 \\
\hline Communication on Trust & 0.21 & 1.56 & 0.121 \\
\hline Communication on Loyalty & 0.20 & 1.82 & 0.071 \\
\hline Handling Complaints on Trust & 0.29 & 2.27 & 0.025 \\
\hline Handling of Complaints against Loyalty & 0.03 & 0.28 & 0.780 \\
\hline Trust in Loyalty & 0.48 & 4.40 & 0.000 \\
\hline
\end{tabular}


The estimated path coefficient describes the strength of the influence between the research variables and the level of significance seen from $p$ value. If $p$ value is smaller than 0.05 , then the effect is said to be significant. Meanwhile, if it is greater than or equal to 0.05 , then the effect is said to be insignificant.

In addition, the influence can be depicted in figure 2 as in table 4. It can be seen that there are three of the seven paths that have a positive and significant influence, while the other four paths have an insignificant effect.

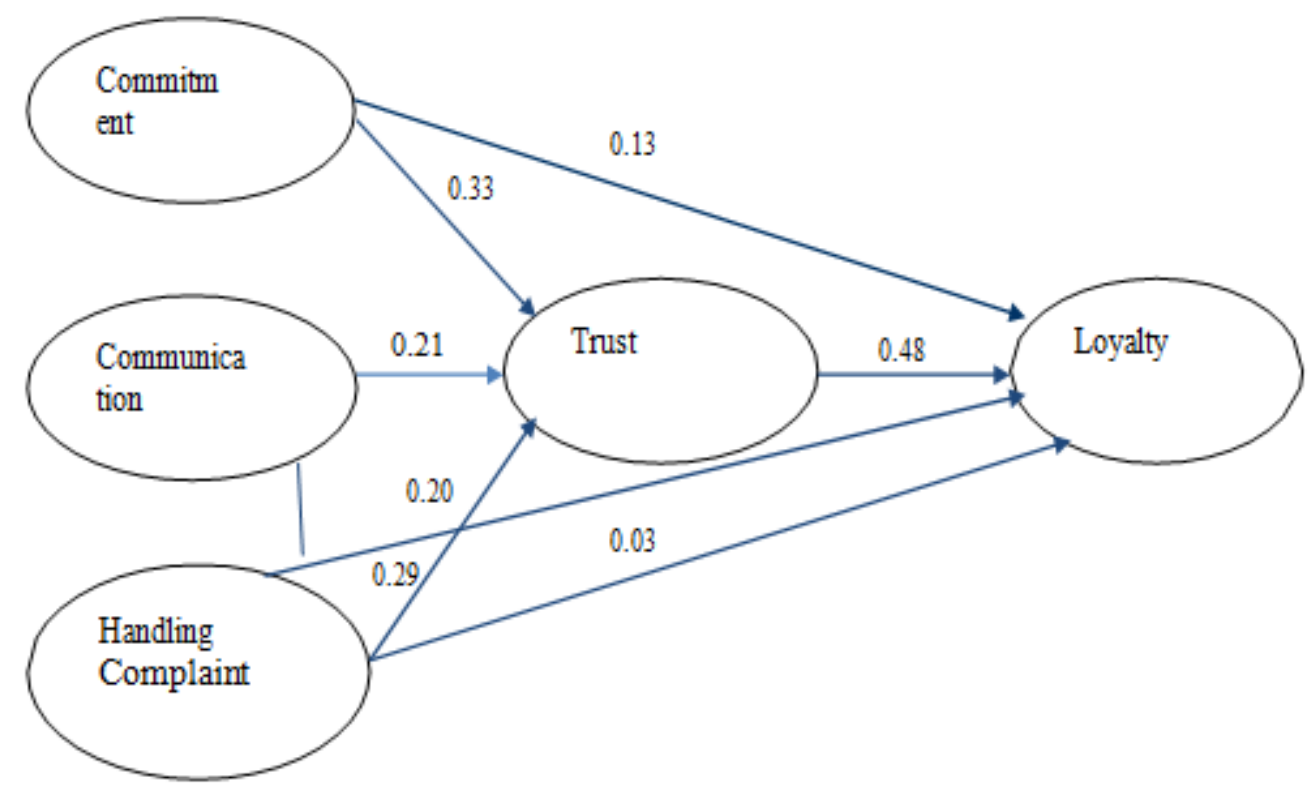

Figure 2: Results of SEM Model Processing.

Commitment has a significant positive effect on trust, so H1 can be accepted. The bank's commitment to serving consumers by optimizing services through e-Banking such as sms banking (short messages), automated teller machines (ATM), and electronic data capture (EDC), can increase consumer confidence in the accuracy of the service data used. Consumers can easily access banking services through e-banking, such as SMS banking, phone banking and internet banking, to e-channels all of which can be done online as a form of trust in the bank. If the bank's commitment to serving consumers can be explained well, it will have a positive impact on consumer confidence. These results are supported by research by Morgan and Hunt (2013) and Bowen \& Shoemaker (2000) which prove that commitment will increase trust. Communication has no effect on consumer confidence in online transactions, so hypothesis $\mathrm{H} 2$ cannot be accepted.

The results of the study have not been able to support the results of research conducted by Morgan \& Hunt (2013) and Anderson \& Narus (2012), that communication is the basis for the creation of trust. Other research that supports this research, conducted by Doney \& Cannon (2007), that communication has no effect on customer trust to the seller or company. This condition may occur, due to differences in the object of research, namely between manufacturing organizations and the banking service industry. Online communication is more passive, meaning that every information is given openly to every consumer, so it has a less different meaning to consumer trust.

Complaint handling has a significant positive effect on trust, indicating that the handling of complaints by banks so far has been able to affect customer trust in the services provided, so hypothesis H3 can be accepted. Research related to handling complaints, namely research conducted by Ah and Wan (2006), if the bank is successful in resolving conflicts that occur properly, it will build consumer confidence in the bank and vice versa if the bank fails to resolve the conflict that 
occurs it will have a negative effect on consumer confidence. Research conducted by Bowo (2003), proves that the factors in building trust are commitment, communication and complaint handling which then proves that trust produces long-term relationships. In addition, with the various advances in technology, consumers can easily access all information completely and quickly, namely online, either through cell phones or through computers (internet). Participants saw this as something that is usually done by all banks, and an obligation that should be carried out by banks to their customers. Therefore, it is possible that the cause of communication does not have a significant effect on consumer trust. Participants saw this as something that is usually done by all banks, and an obligation that should be carried out by banks to their customers. Therefore, it is possible that the cause of communication does not have a significant effect on consumer trust. Participants saw this as something that is usually done by all banks, and an obligation that should be carried out by banks to their customers. Therefore, it is possible that the cause of communication does not have a significant effect on consumer trust.

Commitment, Communication and Complaint Handling do not have a significant effect on consumer loyalty. This finding is different from the research conducted by Ndubisi (2007). The results of the research by Ndubisi (2007) show that commitment is an important factor in building customer loyalty. Banks should recognize the potential of commitment in maintaining loyal customers. In relation to communication. Ndubisi (2007) shows that communication is an important factor in building customer loyalty. When communication is effective between the organization and its customers, better relationships will be established and customers will become more loyal. Ndubisi (2007), found that the relationship between complaint handling and customer loyalty has an indirect influence through trust and perceptions of relationship quality. The ability of service or product providers to handle problems properly will also have a direct effect on customer loyalty.

The research results are different from the research Ndubisi (2007), due to differences in the behavior of bank consumers who are research participants. In the research conducted by Ndubisi, the research participants are consumers who come and make transactions directly at bank counters, while in this study the participants are consumers who often make online transactions (e-banking and m-banking). Online transactions are more used for things such as deposits, transfers, payments and so on so that they are still not optimal or limited in interacting with the bank. One example of the limited direct interaction with consumers carried out by banks online is when an atm card or credit card is lost, consumers can only call the bank's customer service to block the card,

The results of the study show that commitment, communication and the handling of complaints carried out both online and offline is almost the same between banks. consumers feel no need to recommend the bank to other consumers. In addition, at this time it is difficult to make consumers loyal to only one bank or reject another bank because various needs between one consumer and another are different. This can be seen from the tendency of someone to open an account at several banks because each bank offers different benefits. One example, when a consumer wants to transfer money to another consumer but because the bank is owned is different, it will be charged. In order not to be charged a transfer fee, the consumer also opens an account at the same bank. This shows that the hypothesis H4, H5,

Trust has a positive influence significant to consumer loyalty, so that consumer confidence in bank services, will be a determining factor for a loyal customer to the bank. This is supported by research conducted by Bowo (2014), buyer trust can lead to a buyer's desire to establish a long-term relationship. In addition, the results of Ndubisi's research (2007) state that trust is important in building relationships and developing loyalty. This research proves that in running a banking business, they always try to build consumer trust to earn their loyalty. This discussion proves that hypothesis $\mathrm{H} 7$ is 
acceptable.

Testing the suitability of the model through a study of various criteria for model suitability. The following results from the suitability of the model are presented in table 5 .

Table 5: Suitability of SEM Model

\begin{tabular}{|l|c|}
\hline \multicolumn{2}{|c|}{ Fit Model } \\
\hline FIT & 0.463 \\
\hline AFIT & 0.450 \\
\hline GFI & 0.967 \\
\hline SRMR & 0.229 \\
\hline NPAR & 49 \\
\hline
\end{tabular}

Based on the table, it can be seen that not all criteria indicate a good model. It can be seen that the suitability of the model formed can explain all variables of 0.463 . That is, if viewed from the suitability value obtained, the model formed can be said to be quite good. The greater the FIT value obtained, the closer the number 1 then the existing model will be better. When viewed from the AFIT value obtained, the model formed is also quite good. For the value of GFI, if it is close to the value of 1 , it can be said to be an indication of fit, so that the model formed can be said to be appropriate, which is 0.967 . However, the value shown by the SRMR is 0.229 so that the model formed can be said to be not suitable. This is possible because the data values may not match the actual values or the direction of the influence indicator between variables is not known with certainty.

\section{CONCLUSIONS}

Based on the results of the research that has been described, several conclusions were obtained, namely this study found that the three variables studied influenced other variables: Commitment had an effect on trust, complaint handling had an effect on trust, and trust had an effect on loyalty. While the four variables studied did not affect other variables: communication had no effect on trust, commitment had no effect on loyalty, communication had no effect on loyalty, and complaint handling had no effect on loyalty.

Customer relationship marketing is an integrated information system used to plan, schedule and control pre-sales and post-sales activities within an organization. Thus, customer relationship marketing is a communication process especially with consumers that focuses on attracting new potential customers and maintaining and even improving the quality of relationships with existing customers.

Future research agendas are carried out not only on the national banking industry but also on other industries, such as the manufacturing industry, the real estate industry and other industries.

\section{REFERENCES}

1. Ah, KK and Wan, YL (2006). The effect of service recovery on customer satisfaction. Journal of Service Marketing, vol 20, no. 2, pp. 101-111. Retrieved 2006, from ABI/INFORM (Proquest) database.

2. Anderson, JC \& Narus, JA (2012). A Model of Distributor Firm and Manufacturer Firm Working Partnerships. Journal of Marketing, vol. 54, pp. 42-58. Retrieved January, from ABI/ INFORM (Proquest) database.

3. Barnes, J.G. (2010). Secret of Customer Relationship Management. Yogyakarta: Andi. 
4. Barney, J.B., \& Hansen, MH (1994). Trustworthiness as a Source of Competitive Advantage. Journal of Strategic Management, vol. 15, pp. 175-190. Retrieved 1994.

5. Bowen, JT \& Shoemaker, S. (2000). Loyalty: A Strategic Commitment. Cornell Hotel and Restaurant Administration Quarterly, vol. 39, iss. 1, pp. 12-25. From ABI/INFORM (Proquest) database.

6. Bowo, NH (2014, May). Analysis of the influence of trust to achieve long-term relationships. Indonesian Journal of Marketing Science. vol.2. no. 1. Retrived May, 2003, pp. 85-92

7. Chan, S. (2012). Relationship Marketing: Marketing Innovations That Bring Customers To Their Knees. PT. Gramedia Pustaka Utama, Jakarta.

8. $\quad$ Dayat, S. (2012). Building Trusts Online. The McKinsey Quarterly, vol. 4.

9. Doney, PM \& Cannon, JP (2007, April). An Examination of the Nature of Trust in Buyer Seller Relationships. Journal of Marketing, vol 61, No.2, pp. 35-51. Retrieved 1997, from ABI/INFORM (Proquest) database.

10. Dweyer, FR, Schurr, PH,\& Oh, S. (2007). Developing Buyer-Seller Relationships. Journal of Marketing, vol. 51, no. 1, pp. 1127. Retrieved 1987, from (Proquest) database.

11. Ferdinand, A. (2002). Structural Equation Modeling in Management Research. Semarang: BP Undip.

12. Griffin, J. (2015). Customer Loyalty: grow and maintain customer loyalty (Translation). Jakarta: Erlangga.

13. Gundlach, GT and PE Murphy. (2009). Ethical and legal foundations of relational marketing exchanges, Journal of Marketing, vol. 57.

14. Hasibuan, HMSP (2017). Banking Fundamentals. PT Bumi Aksara, Jakarta.

15. Bank Information. (2020, April).

16. BCA information. (2019). vol. 211.

17. Karsono. (2008). The Influence of Customer Satisfaction and Trust on Customer Loyalty as Moderation Variables. Journal of Business and Management, vol. 8, no. 1, pp. 1-18. Retrieved 2008, from (Proquest) database.

18. Morgan, RM and Hunt, SD (2013). The commitment trust theory of relationship marketing. Journal of Marketing, vol. 58, no. 3, pp 20-38. Retrieved July, 1994, from (Proquest).

19. Ndubisi, NO (2007). Relationship marketing and customer royalties. Marketing Intelligence\& Planning, Vol. 25, No. 1, pp. 98106. Retrieved 2007, from ABI/INFORM (Proquest) database

20. (2016). Service Quality: Understanding Customer Perception and Reaction, and its impact on Business. International Journal of Business, vol. 5, no.2. pp. 207-219. Retrieved 2003, from ABI/INFORM (Proquest) database.

21. Setiaatmadja. (2020). Outlook Bank Info.

22. Siamat, D. (2015). Management of Financial Institutions Monetary Policy and Banking (5th ed.). Jakarta: Publishing Institute, Faculty of Economics, University of Indonesia.

23. Singh, J. \& Sirdeshmukh, D. (2014). Agency and Trust Mechanisms in Customer Satisfaction and Loyalty Judgments. Journal of the Academy of Marketing Science, vol. 28, no.1, pp.150-167. Retrieved 2000, from (Proquest) database.

24. Solim. (2017). Structural Guidelines. Generalized Structured Component Analysis GSCA. Poor.

25. Tjiptono, F. (2015). Contemporary Management and Marketing Perspectives. Yogyakarta: Andi. 
26. Winners. (2008).A Framework for Customer Relationship Marketing. New York: The Free Press

27. Shrivastava, Priyanka. "Effect of co-creation on customer experience, trust and brand loyalty." International Journal of Sales \& Marketing Management Research and Development (IJSMMRD) 6.6 : 1-14.

28. Neelakanteswara, P., and P. SURYANARAYANA Babu. "Efficient trust management technique using neural network in cloud computing." J Comput Netw Wirel Mobile Commun 9.1: 29-40.

29. Barte, R. H. "Foreign trust and confidence in Philippine stocks using Benfords law." International Journal of Research in Business Management (IMPACT)4.6 : 67-74.

30. Sulthana, N. A., and Abdulla Saleh Mattar Al Balushi. "Study on the effectiveness of advertisement in BankMuscat." International Journal of Business Environment, 7 (3): 53-60. 